\title{
Eläinten hyvinvointi - mitä se on ja kuinka sitä tutkitaan?
}

\author{
Jaakko Mononen \\ Kuopionyliopisto, Soveltavan biotekniikan instituutti,PL 1627,70211 Kuopio,jaakko.mononen@uku.fi
}

\section{Eläinten hyvinvointi yhteiskunnallisena kysymyksenä}

Eläimiä pidetään monessa tarkoituksessa: ravinnon, nahkojen, villan, turkisten ja muiden eläinperäisten tuotteiden vuoksi, koe-eläiminä, lemmikkeinä ja harrastuseläiminä sekä eläintarhoissa ja viihteen (esimerkiksi sirkukset ja elokuvat) palveluksessa. Pieni osa suomalaisistakin kyseenalaistaa eläinten pidon kokonaisuudessaan, ja he olisivat halukkaita kehittämään yhteiskunnan, jossa ei ole eläinten hyötykäyttöä. Nämä ihmiset puhuvat eläinten absoluuttisista oikeuksista, oikeudesta vapauteen ihmisen vallasta. Heidän edustamansa yhteiskunnallinen liike on eläinoikeusliike (Aaltola 2000).

"Hyötyeläimet" ovat kuitenkin olemassa oleva tosiasia kaikissa tämänhetkisissä yhteiskuntajärjestelmissä, ja yhteiskunta ilman ihmisen vallan alla eläviä eläimiä on utopistinen ajatus. Eläinten hyvinvoinnin kannalta ei ole ratkaisevaa se, onko eettisesti oikein pitää eläimiä, vaan se kuinka näitä eläimiä pidetään, koska niitä kuitenkin pidetään. Tällöin puhutaan eläinten oikeuksista vapauteen kärsimyksestä eli eläinten hyvinvoinnista. Tätä näkemystä edustaa eläinasialiike (Aaltola 2000). Näkemys on yhteiskunnassa myös laajasti hyväksytty ja se näkyy esimerkiksi eläinsuojelusäädösten kehittymisenä.

Eläinten hyvinvointi on yleinen julkisen keskustelun aihe. Keskustelussa käytetään muun muassa eettisiä, poliittisia, taloudellisia ja luonnontieteellisiä argumentteja. Erilaiset näkemykset johtavat usein juupas-eipäs -väittelyihin. Yksittäisten ihmisten eettiset kannat saattavat myös vaihdella eläinlajista ja sen käyttötarkoituksesta riippuen. Joku voi pitää turkiksia ylellisyystuotteena ja siksi turhana, mutta harrastaa silti esimerkiksi ratsastusta. Hyvinvointikeskusteluun osallistujien tulisi ymmärtää, että kyse on laajasta yhteiskunnallisesta kysymyksestä, jota voidaan lähestyä useista eri näkökulmista (Fraser \& Leonard 1993), ja on mahdotonta sanoa, kenen näkemys on oikea ja kenen väärä (Airaksinen 1996). Vasta silloin päästään rakentavaan keskusteluun, mikä voi auttaa pääsyssä tavoitteeseen, joka on ihmisen vallan alla elävien eläinten hyvinvoinnin takaaminen.

\section{Eläinten hyvinvointi luonnontieteellisenä kysymyksenä}

Eläinten hyvinvoinnin tutkimus kuuluu kolmen tieteenalan piiriin, ja nämä alat ovat osittain päällekkäisiä. Perinteinen eläinlääketiede keskittyy eläinten terveyteen ja perinteinen kotieläintiede muun muassa eläinten ruokintaan, jalostukseen ja tuotantoteknologiaan. Näiden rinnalle on tullut uutena alana soveltava etologia, jota saatetaan joskus nimittää yksinään "eläinten hyvinvointitieteeksi", vaikka se syntyi 1960luvulla osana eläinlääketiedettä (Dawkins 1983). Soveltava etologia korostaa perinteistä eläinlääketiedettä ja kotieläintiedettä enemmän eläinten vapaamman käyttäytymisen merkitystä hyvinvoinnin kannalta. Tämä artikkeli käsittelee eläinten hyvinvointia lähinnä soveltavan etologian näkökulmasta. On kuitenkin hyvä muistaa, että vapaamman käyttäytymisen ja eläimiä vähemmän stressaavan eläintuotannon toteuttaminen vaatii muutoksia muun muassa tuotantotiloissa, ruokintamenetelmissä ja jopa eläinten jalostamista. Elintarviketuotannossa eivät puolestaan tule kysymykseen sellaiset käyttäytymisen vapautta lisäävät muutokset, jotka ovat uhka elintarvikehygienialle.

Hyvinvointi on eläinyksilön subjektiivinen tunnetila, joka riippuu eläimellä olevien sopeutumien ja eläimen ympäristön asettamien haasteiden vuorovaikutuksesta (Fraser ym. 1997). Sopeutumat ovat seurausta geeneistä ja eläimen yksilönkehityksen aikaisista tapahtumista. Ympäristöstä tulevat haasteet johtuvat fyysisestä ja sosiaalisesta kasvatusympäristöstä sekä eläinten pitoon liittyvistä toimenpiteistä.

Esimerkki valottaa asiaa. Lehmä on lajina sopeutunut liikkumaan laiduntaessaan ja käyttämään suuren osan ajastaan syömiseen. Parteen kytketty lypsylehmä saa kyllä riittävästi ravintoa, mutta lehmällä on myös tarve liikkua ja nähdä itse vaivaa ravintonsa eteen. Ravinnon tarve siis tyydyttyy, mutta syömiseen liittyvän käyttäytymisen tarve ei välttämättä tyydyty. Toisaalta voisi olettaa, että eläin yksilönkehityksensä aikana oppii liikkumattomuuteen ja helppoon ravinnon saantiin, eikä se niistä kärsi. Juuri tässä astuu kuvaan soveltavan etologian tutkimus: tutkimuksen keinoin voidaan selvittää vaihtoehtoisten kasvatusmenetelmien etuja ja haittoja eläinten hyvinvoinnin kannalta. 


\section{Kuinka eläinten hyvinvointia tutkitaan?}

Eläinten hyvinvointia ei voida suoraan mitata, koska hyvinvointi on eläinyksilön subjektiivinen tunnetila (Dawkins 1983). Hyvinvointia voidaan kuitenkin arvioida epäsuorasti eläinten käyttäytymisen ja fysiologian sekä terveyden ja tuotannon avulla.

Lähtökohtana hyvinvointitutkimuksille ovat eläinten käyttäytymistarpeet, joita voidaan selvittää kahdella eri tavalla. Ensin tarvitaan tietoa eläinlajin käyttäytymisestä luonnollisissa tai puoliluonnollisissa oloissa. Tietoa voidaan kerätä lajin villistä kantamuodosta, jos se on vielä olemassa. Domestikoituja eläimiä voidaan puolestaan pitää puoliluonnollisissa oloissa, joissa niiden tutkiminen on melko helppoa. Tällaiset tutkimukset ovat osoittaneet, että lajista ja sen domestikaatiohistorian pituudesta riippumatta domestikaatio ei ole karsinut juuri mitään käyttäytymismuotoja. Useimmat emakot tekevät tiineyden loppupuolella pesänrakennusliikkeitä, vaikka niillä ei ole pesänrakennustarpeita tai vaikka niille olisi tarjolla valmis pesä (Jensen 1999: s. 54; Jensen 2002). Kaikki ketut järsivät purukapulaa (luultavimmin puruluun korvikkeena), jos niille tarjotaan siihen mahdollisuus, vaikka eläinten ravinnontarve olisi tyydytetty (Korhonen ym. 2002).

Kaikkia luonnon tarjoamia mahdollisuuksia ja virikkeitä ei kuitenkaan voida tarjota eläimille kasvatusoloissa, ja siksi on pyrittävä selvittämään ne eläimen ympäristön avainpiirteet (Nicol 1994), joilla on eläimille ja niiden hyvinvoinnille suurin merkitys. Yksittäisten ympäristön piirteiden merkitystä eläimelle voidaan selvittää valintakokeilla. Preferenssitesteissä (mieltymystesteissä) eläimelle tarjotaan vapaus valita kahden tai useamman ympäristön välillä. Preferenssitesteillä on osoitettu muun muassa, että lehmät valitsevat mieluummin olkikuivitetun betonipohjaisen kuin hiekkapohjaisen makuupaikan (Manninen ym. 2001, Norring \& Manninen 2003). Yksin pidetyt siat puolestaan valitsevat mieluummin karsinan, jonka vieressä on toisen sian karsina, kuin karsinan, jossa naapuria ei ole (Broom \& Johnson 1993: s. 149-152). Valintakokeissa voidaan käyttää hyväksi myös välineellistä oppimista. Eläimet opetetaan tekemään temppu eli työ, esimerkiksi painamaan vipua tai nappia, jonka avulla ne saavat hyödykkeen. Työn määrää koesarjoissa muunnellaan, ja mitä tärkeämpi tutkittava hyödyke eläimelle on, sitä enemmän se on valmis tekemään työtä saadakseen hyödykkeen (Dawkins 1990). Myös välineelliseen ehdollistamiseen perustuvilla kokeilla on osoitettu, että lajitoverin seura on sialle tärkeää (Ladewig \& Matthews 1996).

Kun luonnollisia ja puoliluonnollisia oloja tutkimalla, ja mahdollisesti myös valintakokeiden avulla, on seulottu ympäristön piirteistä ne, jotka ovat eläinten kannalta todennäköisesti tärkeimpiä, on aika tehdä koe, jossa tutkitaan näiden piirteiden vaikutusta eläinten käyttäytymiseen ja fysiologiaan sekä terveyteen ja tuotantoon. Yleensä tämä tarkoittaa sitä, että vallitsevaa, vanhaa kasvatustapaa verrataan uuteen, vaihtoehtoiseen kasvatustapaan, jossa eläimellä on siis enemmän käyttäytymisen vapautta. Eläinten stressi voi ilmentyä epänormaalina käyttäytymisenä tai fysiologisina muutoksina. Rajoitetussa ja virikkeettömässä tilassa pidetty hevonen saattaa "kutoa" eli huojuttaa itseään puolelta toiselle (Jensen 1999). Kyseessä on stereotyyppinen käyttäytyminen: liikesarja, jolla ei ole mitään ilmeistä tarkoitusta tai päämäärä. Lehmät, jotka ovat saaneet riittävästi ravintoa, mutta joiden syömiskäyttäytyminen on jäänyt tyydyttämättä, voivat puolestaan harrastaa stereotyyppistä kielen pyöritystä. Stressi voi johtaa myös muun muassa aggressioihin.

Stressaava tilanne kuluttaa energiaa (Moberg 2000), ja siksi stressiin liittyy elimistön energiavarastojen käyttöönottoa tehostavia fysiologisia muutoksia. Näistä hyvinvoinnin mittarina on käytetty eniten lisämunuaisen kuorikerroksen toimintaa. Esimerkiksi kotieläinten pelkoreaktiot ihmistä kohtaan heijastuvat kuorikerroksen lisääntyneenä glukokortikoidien erityksenä ja jopa koko lisämunuaisen koon suurenemisena (Hemsworth \& Barnett 2000).

Eläimen joutuminen toistuvasti epämiellyttäviin stressaaviin tilanteisiin voi johtaa myös jopa kasvun ja lisääntymisen heikkenemiseen. Porsaiden ja monien muiden eläinlajien kasvukäyrissä tapahtuu notkahdus, jos niitä sekoitetaan vieraiden eläinten kanssa ja ne joutuvat selvittelemään sosiaaliset suhteensa uudelleen (Broom \& Johnson 1993, s. 114-115 ). Liian suuri eläintiheys heikentää lihakarjan kasvua (Ruis-Heutinck ym. 2000). Ihmisen pelko heikentää tuotantoa munivilla kanoilla, broilereilla, sioilla ja lypsykarjalla (Hemsworth \& Barnett 2000) ja lisääntymistä ketuilla (Rekilä 1999, s. 46).

Lisämunuaisen glukokortikoidit heikentävät elimistön immuunijärjestelmää, mikä vaikuttaa osaltaan siihen, että jatkuva stressi voi johtaa sairastumiseen (Castrén 1997, s. 49-52). Kasvatusolot voivat vaikuttaa terveyteen suoraviivaisemminkin. Makuualustan epämukavuus ja liukkaus ja niistä johtuva makuulle käymisen ja makuulta nousemisen vaikeus voi itsessään olla vakava stressitekijä ja johtaa vammoihin (Fraser \& Broom 1990, s. 343-344; Ladewig 2000). 


\section{Mitä eläinten hyvinvointitutkimuksilla on saavutettu?}

Tie havaitusta hyvinvointiongelmasta tutkimuksen kautta uuden, eläinten hyvinvoinnin kannalta paremman kasvatusmenetelmän käyttöön ottoon on mutkainen ja hidas. Tämä voi ymmärrettävästi turhauttaa innokkaimmat eläinsuojelijat, mutta näin yhteiskuntamme toimii. Alussa on oltava tarkka käsitys siitä, mikä vanhassa menetelmässä on ongelmana, ja lisäksi tarkka käsitys siitä, kuinka ongelma voitaisiin ratkaista. Tämä ei ole aina itsestään selvää, vaan aivan liian usein eläimille vaaditaan vain ympäripyöreästi vapautta lajinmukaiseen käyttäytymiseen.

Ongelmia ei yleensä pystytä ratkaisemaan yhdessä tutkimuksessa, vaan vaaditaan useiden tutkimusten sarja. Pahimmillaan uusi kasvatusmenetelmä voi osoittautua vanhaa huonommaksi, ja joudutaan kehittämään taas uusi vaihtoehto. Kun vaihtoehto on tutkimuksen keinoin osoitettu vanhaa menetelmää paremmaksi, voi yhteiskunta niin halutessaan siirtyä uuteen menetelmään, ja tavoite, eläinten hyvinvoinnin paraneminen on saavutettu. Lopulliseen päätökseen vaikuttavat kuitenkin etenkin taloudelliset seikat ja arvoihin liittyvät poliittiset näkökannat.

Tutkimusmenetelmätkään eivät ole ongelmattomia. Monet yllä esitetyt suoraviivaiset tulkinnat ja yleistykset koskien eläinten tarpeiden tutkimista sekä stressin mittaamista ja sen vaikutuksia voidaan kyseenalaistaa (Rushen \& de Pasillé 1992). Yksi eläinten hyvinvointitutkimusten "saavutuksista" onkin ollut hämmennys siitä, että miten hyvinvointia pitäisi tai voi tutkia. Eläinten hyvinvointitiede soveltavan etologian muodossa on vain noin 40 vuotta vanha tieteenala ja sen tutkimusmenetelmät ovat vielä kiivaassa kehitysvaiheessa. Samaan aikaan tältä soveltavalta alalta odotetaan kuitenkin konkreettisia tuloksia ja ehdotuksia eläinsuojelusäädösten ja neuvonnan pohjaksi. Menetelmiä koskeva perustutkimus tehdään pakon sanelemana osittain osana soveltavia tutkimuksia. Tarve menetelmiin kohdistuvan perustutkimuksen lisäämiseen on ilmeinen.

Parhaimmillaan eläinten hyvinvointitutkimus tuottaa kuitenkin helposti tulkittavia ja käytäntöön sovellettavia tuloksia. Hoitajan ja eläimen välisen hyvän suhteen merkitys eläinten hyvinvoinnin kannalta on selkeä. Useimmat eläinten hoitajat toimivat luonnostaan niin, että eläimet eivät hoitajaansa pelkää, mutta toisaalta hoitajien asennekoulutuksella on kuitenkin saatu vähennettyä eläinten pelkoa ja stressiä sekä parannettua tuotantotuloksia (kts. Hemsworth \& Barnett 2000). Myös eläinten sosiaalisen järjestelmän vakaana pitäminen sekä fyysinen ympäristö, joka mahdollistaa eläinten tarkoituksenmukaisen käyttäytymisen sosiaalisissa tilanteissa (esim. tilaa väistää) näkyvät usein tutkimuksissa selvästi vähentyneenä stressinä. Sen sijaan eläinten ympäristön fyysinen virikkeellistäminen sen jälkeen, kun eläimillä on jo kohtuullinen liikkumisen vapaus, ei välttämättä aina näy stressi-, tuotanto- ja terveysmuuttujissa, vaikka eläimet valinnoillaan osoittaisivatkin, että virikkeellä on niille merkitystä.

Elinympäristön ennustettavuus ja kontrolloitavuus vähentävät stressiä (Keeling \& Jensen 2002). Sosiaaliset suhteet eläinten tai eläinten ja ihmisen välillä ovat dynaamisia, ja siksi voikin olettaa, että huonosti toimivat suhteet vähentävät sekä elinympäristön ennustettavuutta että kontrolloitavuutta. Fyysiset virikkeet taas vastaavat monesti enemmänkin eläinten tarpeeseen toteuttaa monipuolisemmin ympäristön tutkiskelua (eksploraatiota) kuin spesifisesti johonkin tiettyyn tarpeeseen. Esimerkiksi minkit uivat luonnossa ravintoa hankkiessaan, ja domestikoidut minkitkin uivat, jos niille tarjotaan siihen mahdollisuus (Jeppesen ym. 2001). Ne ovat jopa valmiita tekemään työtä päästäkseen uimaan (Mason ym. 2001). On kuitenkin hyvin mahdollista, että jollain muulla virikkeellä voi olla minkin hyvinvoinnin kannalta yhtä suuri vaikutus kuin uima-altaalla (Jeppesen ym. 2001, Mohaibes ym. 2003), joka on turkistiloilla käytännössä mahdoton ratkaisu.

\section{Johtopäätökset}

Kysymys eläinten hyvinvoinnista on arvosidonnainen. Huonontunut hyvinvointi on seurausta eläinten sopeutumiskyvyn ja ympäristön eläimelle asettamien haasteiden yhteensopimattomuudesta. Hyvinvointi on eläinyksilön subjektiivinen tuntemus, mutta eläinten hyvinvointia erilaisissa kasvatusjärjestelmissä voidaan verrata eläinten hyvinvointitieteessä käytettävillä mittausmenetelmillä. Uusien kasvatusjärjestelmien käyttöön otto on yhteiskunnallinen kysymys, ja siihen vaikuttavat muutkin tekijät kuin tutkimustulokset. 


\section{Kirjallisuus}

Aaltola, E. 2000. Eläinten moraalinen arvo ja eläinten käyttö. Koekukko 20(2) [verkkojulkaisu]. Viitattu 8.12.2003. Julkaistu 25.1.2001. Saatavilla Internetissä: http://www.uku.fi/laitokset/vkek/Koekukko/Koeku22000/Koekukko22000.htm

Airaksinen, T. 1996. Arvo-objektivismi tappaa keskustelun. Helsingin Sanomat, Vieraskynä, 10.10.1996.

Broom, D.M. \& Johnson, K.G. 1993. Stress and animal welfare. Chapman \& Hall. London, UK.

Castrén, H. 1997. Kotieläinten käyttäytyminen ja hyvinvointi. Helsingin yliopiston Maaseudun tutkimus- ja koulutuskeskus. Mikkeli, Suomi.

Dawkins, M.S. 1983. Animal suffering: the science of animal welfare. Chapman \& Hall. London, UK.

Dawkins, M.S. 1990. From an animals point of view: motivation, fitness, and animal welfare. Behav. Brain Sci. 13: 1-61.

Fraser, A.F. \& Broom, D.M. 1990. Farm animal behaviour and welfare. Baillière Tindall. London, UK.

Fraser, D. \& Leonard, M.L. 1993. Farm animal welfare. Kirjassa: Animal production in Canada. Toim. J. Martin, R.J. Hudson \& B.A. Young. University of Alberta. Alberta, Canada. Sivut 253-270.

Fraser, D., Weary, D.M., Pajor, E. A. \& Milligan, B.N. A scientific conception of animal welfare that reflects ethical concerns. Anim. Welfare 6: 187-205.

Hemsworth, P.H. \& Barnett, J.L. 2000. Human-animal interactions and animal stress. Kirjassa: The biology of animal stress. Basic principles and implications for animal welfare. Toim. G.B. Moberg \& J.A. Mench. CABI Publishing. Oxon. UK. Sivut 309-335.

Jensen, P. 1999. Djurens beteende och orsakerna till det. LTs förlag. Stockholm, Sverige.

Jensen, P. 2002. Behaviour of pigs. Kirjassa: The ethology of domestic animals. An introductory text. Toim. P. Jensen. CABI Publishing. Oxon, UK. Sivut 159-172.

Jeppesen, L.L., Pedersen, V., Simonsen, T. \& Hansen C.P.B. 2001. Simning är inget biologiskt behov hos mink. Finsk Pälstidskrift 73(5): 127-129.

Keeling, L. \& Jensen, P. 2002. Behavioural disturbances, stress and welfare. Kirjassa: The ethology of domestic animals. An introductory text. Toim. P. Jensen. CABI Publishing. Oxon, UK. Sivut 79-98.

Korhonen, H., Jauhiainen, L. Niemelä, P. \& Sauna-aho, R. 2002. Wooden blocks and straw as environmental enrichments for juvenile blue foxes (Alopex lagopus). Acta Ethol. 5: 29-37.

Ladewig, J. 2000. Chronic intermittent stress: a model for the study of long-term stressors. Kirjassa: The biology of animal stress. Basic principles and implications for animal welfare. Toim. G.B. Moberg \& J.A. Mench. CABI Publishing. Oxon. UK. Sivut 159-169.

Ladewig, J. \& Matthews, L. 1996. The role of operant conditioning in animal welfare research. Acta Agric. Scand., Sect A, Anim Sci. Suppl. 27: 64-68.

Manninen, E., de Pasillé, A.M., Rushen, J., Norring, M. \& Saloniemi, H. 2001. Makuualustan vaikutus lypsylehmien makuukäyttäytymiseen, tuotokseen ja terveyteen kylmäpihatoissa. Teoksessa: Eläinten hyvinvointitutkimusseminaari, 5.-6.10.2001. Toim. Laura Hänninen. Helsingin yliopisto, Eläinlääketieteellinen tiedekunta, Kliinisen eläinlääketieteen laitos. Helsinki, Suomi. Sivu 23.

Mason, G.J., Cooper, J. \& Clarebrough, C. 2001. Frustrations of fur-farmed mink. Nature 410: 35-36.

Moberg, G.B. 2000. Biological response to stress: implications for animal welfare. Kirjassa: The biology of animal stress. Basic principles and implications for animal welfare. Toim. G.B. Moberg \& J.A. Mench. CABI Publishing. Oxon. UK. Sivut 1-21.

Mohaibes, M., Mononen, J. \& Pyykönen, T. 2003. The effects of swimming pool oor extra space on behaviour of mink. Nordiske Jordbruksforskeres Forening, NJF's Subsection for fur animals, NJF-seminar no. 354, Lillehammer, Norway, 8-10 October 2003. 6 sivua.

Nicol, C. 1994. Behaviour and welfare. Kirjassa: Livestock Housing. Toim. C.M. Wathes \& D.R. Charles. CAB International. Oxon, UK. Sivut 69-93.

Norring, M. \& Manninen, E. 2003. Makuuparren pohjamateriaalin tuttuuden vaikutus lehmien parsivalintoihin. Teoksessa: 2. Eläinten hyvinvointi -tutkimusseminaari, 3.-4.10.2003. Toim. Sari Hänninen. Kuopion yliopisto, Soveltavan biotekniikan instituutti Sivu 17.

Rekilä, T. 1999. Behavioural tests in welfare research of foxes. Väitöskirja. Kuopion yliopiston julkaisuja C. Luonnontieteet ja ympäristötieteet 92 .

Ruis-Heutinck, L.F.M., Smits, M.C.J., Smits, A.C. \& Heeres, J.J. 2000: Effects of floor type and floor area on behaviour and carpal joint lesions in beef bulls. Teoksessa: Improving health and welfare in animal production: Proceedings of sessions of the EAAP commission on animal management and health, the Hague, the Netherlands, 2124 August 2000. Toim. H.J. Blokhuis, E.D. Ekkel \& B. Wechsler. Wageningen Pers. Wageningen, Netherlands. Sivut: $29-36$.

Rushen, J. \& de Pasillé, A.M.B 1992. The scientific assessment of the impact of housing on animal welfare. A critical review. Can. J. Anim. Sci. 72: 721-743. 